\title{
LETTER
}

\section{Carbonic fluid inclusions in amphibolite-facies pelitic schists from Bodonch area, western Mongolian Altai}

\author{
Oyun-Erdene ZorigtKhUU, ${ }^{* * *}$, Toshiaki TsuNOGAE, ${ }^{*, * * *}$ and Batulzii DASH ${ }^{* *}$ \\ ${ }^{*}$ Graduate School of Life and Environmental Sciences, University of Tsukuba, Ibaraki 305-8572, Japan \\ ${ }^{* *}$ School of Geology and Petroleum Engineering, Mongolian University of Science and Technology, \\ Ulaanbaatar 46-654, Mongolia \\ *** Department of Geology, University of Johannesburg, Auckland Park 2006, \\ Republic of South Africa
}

\begin{abstract}
We report first fluid inclusion data on amphibolite-facies pelitic schists from Bodonch area of western Mongolian Altai in the Central Asian Orogenic Belt. Three categories of fluid inclusions have been observed in quartz: dominant primary and secondary inclusions, and least dominant pseudosecondary inclusions. The melting temperatures of all the categories of inclusions lie in the narrow range of $-57.5^{\circ} \mathrm{C}$ to $-56.6{ }^{\circ} \mathrm{C}$, close to the triple point of pure $\mathrm{CO}_{2}$. Homogenization of fluids occurs into liquid phase at temperature between $-33.3^{\circ} \mathrm{C}$ to +19.4 ${ }^{\circ} \mathrm{C}$, which convert into densities in the range of $0.78 \mathrm{~g} / \mathrm{cm}^{3}$ to $1.09 \mathrm{~g} / \mathrm{cm}^{3}$. The estimated $\mathrm{CO}_{2}$ isochores for primary and pseudosecondary high-density inclusions is broadly consistent with the peak metamorphic condition of the studied area $\left(6.3-7.3 \mathrm{kbar}\right.$ at $\left.655^{\circ} \mathrm{C}\right)$. The results of this study, together with the primary and pseudosecondary nature of the inclusions, indicate $\mathrm{CO}_{2}$ was the dominant fluid component during the peak amphibolitefacies metamorphism of the study area. The examined quartz grains are texturally associated with biotite, kyanite and staurolite, which are regarded as high-grade minerals formed during prograde to peak metamorphism. Therefore quartz probably formed by high-grade metamorphism and the primary fluid inclusions trapped in the minerals probably preserve fluids at around peak metamorphism.
\end{abstract}

Keywords: Fluid inclusion, Microthermometry, $\mathrm{CO}_{2}$, Altai Orogeny, Central Asian Orogenic Belt, Mongolia

\section{INTRODUCTION}

The Central Asian Orogenic Belt (CAOB), also known as Altaids (Sengör et al., 1993), located between the Archean Siberian Craton to the north and the Tarim and North China Cratons to the south, is regarded as one of the largest accretionary and collisional orogen in the world (Xiao et al., 2010; Rojas-Agramonte et al., 2011) (Fig. 1b). Detailed petrological and geochronological studies on the CAOB therefore provide useful information of the $P-T-t$ history of the orogeny as well as the tectonic evolution of East Asia. The Altai Orogen in the southwestern margin of the $\mathrm{CAOB}$ contains various volcano-sedimentary rocks that were deformed and metamorphosed under various $P-T$ conditions from greenschist to amphibolite and partly granulite facies (Coleman, 1989; Windley et al., 2002; Chen et al., 2006). Recently Zorigtkhuu et al. (2011) per-

doi:10.2465/jmps.111020e

O. Zorigtkhuu, oyuk_m@yahoo.com Corresponding author

T. Tsunogae, tsunogae@geol.tsukuba.ac.jp formed a detailed petrological study of pelitic schists and amphibolites from Bodonch area in the Mongolian Altai Orogen, and obtained peak $\left(640-690{ }^{\circ} \mathrm{C} / 6.3-10.7 \mathrm{kbar}\right)$ and retrograde $\left(560-570{ }^{\circ} \mathrm{C} / 3.0-3.5 \mathrm{kbar}\right) P-T$ conditions and a clockwise $P-T$ path. However, no detailed study on the evolution of fluid associated with high-grade metamorphism in the Altai Orogen has been done. Chemical and physical characterization of fluids in lower crust has been the focus of recent petrological research, particularly in understanding the stability of mineral assemblages and fluid-rock interaction processes (e.g., Santosh and Omori, 2008; Touret, 2009). Several attempts have been made to infer the nature of synmetamorphic fluids, including thermodynamic calculations of mineral assemblages and geochemical and isotopic studies of high-grade metamorphic rocks. Among these, detailed investigation of fluid inclusions trapped in various metamorphic minerals provides potential tools in obtaining direct information on the nature and composition of fluids at various stages of metamorphic processes (e.g., Touret, 1985, 2001, 2009; To- 


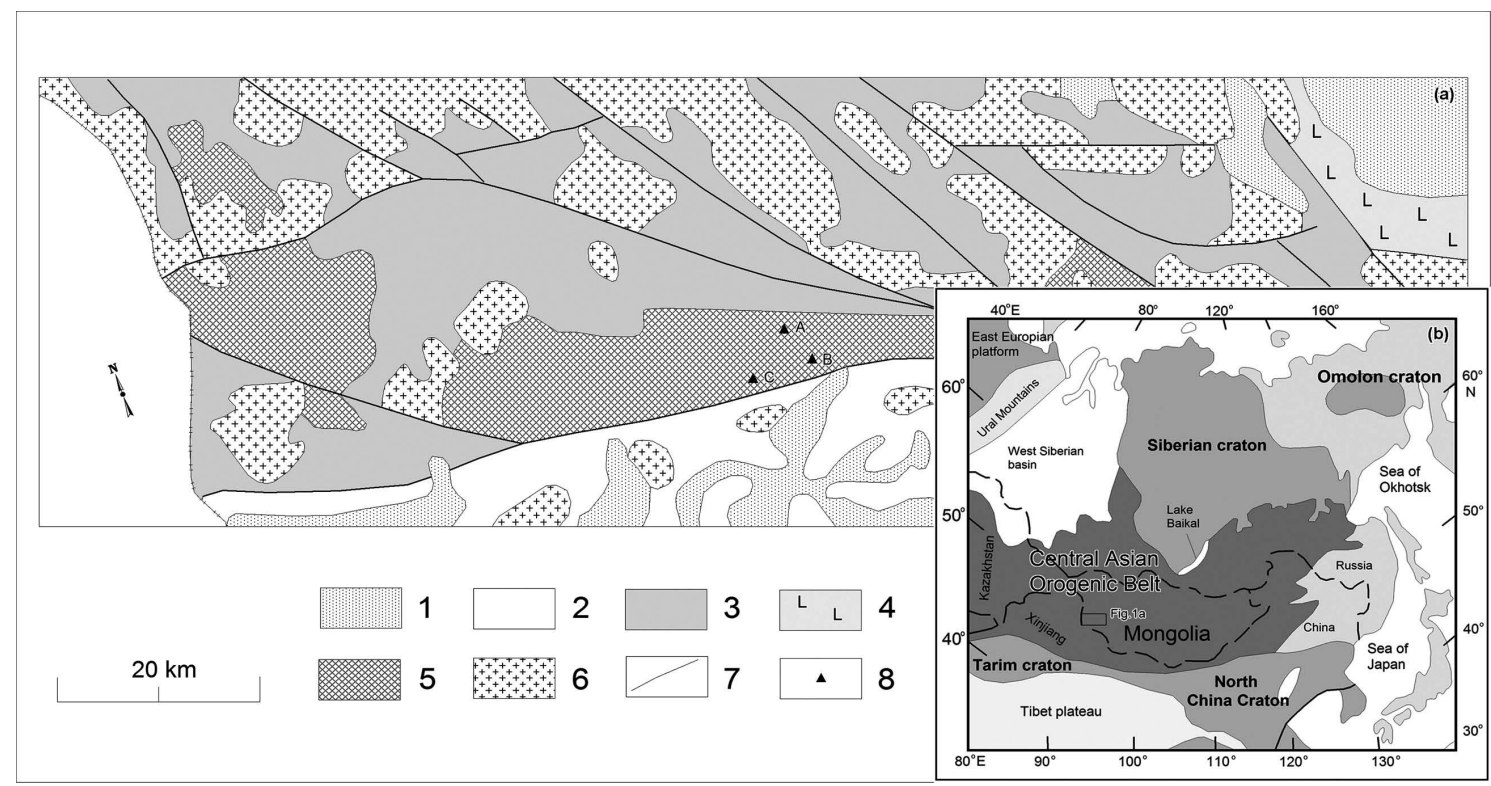

Figure 1. (a) Schematic geological map of the study area (modified after Kozakov et al., 2002). 1, Mesozoic and Cenozoic basins; 2, Hercynides of the South Mongolian Zone; 3, Early Caledonides; 4, Late Caledonides; 5, Metamorphic complexes; 6, Middle and Late Paleozoic granitoid; 7, Faults; 8, Sample locations; A, samples 446, 05-126, and BD10-5; B, samples 05-128, 05-134, and 443; C, samples 24-5, 24-8, 24-9, and 24-12. (b) Simplified tectonic map of the Central Asian Orogenic Belt and adjacent cratons (modified after Jahn et al., 2000).

uret et al., 2011; Zheng et al., 2011). The importance of fluids in accretion-collision belts has been investigated in various studies, including geophysical evidence that attest to the presence of fluids and fluid-rock interaction processes (e.g., Naganjaneyulu et al., 2011; Naidu et al., 2011). In this study, we present new microthermometric data of fluid inclusions trapped in pelitic schists from Bodonch area, and discuss the nature of fluid during highgrade metamorphism of the Altai Orogen in Mongolia.

\section{PETROGRAPHY}

The studied samples were collected from the central part of Bodonch area, southwestern Mongolia (Fig. 1a). In this study we examined several lithologies including garnetbiotite-sillimanite schist, staurolite-biotite schist, garnetkyanite schist, garnet-staurolite schist, garnet-kyanitestaurolite schist, garnet-cordierite-staurolite schist, garnet anthophyllite schist, and amphibolite. For fluid inclusion investigation we have analyzed 11 samples. However, due to the absence of fluid inclusion in most of the samples, we have selected four samples that contain inclusions suitable for microthermometric measurements. Petrographical characters of the samples (garnet-kyanite-staurolite schist, garnet-cordierite-staurolite schist, garnet-biotite-sillimanite schist and staurolite-biotite schist) are briefly discussed below. As the analyzed fluid inclusions are present in quartz, we described the mineral assemblage including quartz in detail.
The garnet-kyanite-staurolite schist (sample 446) is composed of coarse-grained porphyroblastic garnet $\left(\mathrm{Alm}_{56-66} \operatorname{Prp}_{7-14} \mathrm{Grs}_{9-11} \mathrm{Sps}_{10-26}\right)$, kyanite, staurolite $\left(\mathrm{X}_{\mathrm{Mg}}=\right.$ $\mathrm{Mg} /(\mathrm{Fe}+\mathrm{Mg})=0.15-0.23)$, paragonite, biotite $\left(\mathrm{X}_{\mathrm{Mg}}=\right.$ $0.55)$, and plagioclase $\left(\mathrm{An}_{37} \mathrm{Ab}_{63}\right)$ in the matrix of quartz. Garnet contains fine-grained inclusions of rutile and ilmenite. Kyanite contains numerous fine-grained inclusions of rutile. The analyzed coarse-grained quartz is texturally associated with biotite and kyanite, which are regarded as the minerals formed during high-grade metamorphism. We therefore regard that primary fluid inclusions trapped in quartz probably preserve fluids around peak metamorphism. Zorigtkhuu et al. (2011) estimated metamorphic conditions of $655-695^{\circ} \mathrm{C}$ and 7.8-10.6 kbar using mineral equilibrium modeling technique for the assemblage.

The garnet-cordierite-staurolite schist (sample 05128) comprises coarse-grained poikiloblastic garnet $\left(\mathrm{Alm}_{67-69} \operatorname{Prp}_{24-25} \mathrm{Grs}_{6-7} \mathrm{Sps}_{1}\right)$ and cordierite $\left(\mathrm{X}_{\mathrm{Mg}}=0.80\right)$, with medium- to fine-grained biotite $\left(\mathrm{X}_{\mathrm{Mg}}=0.71\right)$ and staurolite $\left(\mathrm{X}_{\mathrm{Mg}}=0.27\right)$ in the matrix of quartz. Garnet contains numerous inclusions of quartz and ilmenite. The examined quartz is a matrix medium-grained phase and occurs together with biotite. The calculated $P-T$ condition of the assemblage is $635-685^{\circ} \mathrm{C}$ and $6.3-7.3 \mathrm{kbar}$ (Zorigtkhuu et al., 2011).

The garnet-biotite-sillimanite schist (sample 24-8) is composed of idioblastic to subidioblastic garnet $\left(\mathrm{Alm}_{76-78} \operatorname{Prp}_{16-18} \mathrm{Grs}_{3-4} \mathrm{Sps}_{2-3}\right)$ with biotite $\left(\mathrm{X}_{\mathrm{Mg}}=0.55\right)$, fi- 
brolitic sillimanite, and plagioclase $\left(\mathrm{An}_{33} \mathrm{Ab}_{67}\right)$ in the matrix of quartz. Garnet contains minor inclusions of quartz and biotite. The garnet-biotite assemblage in the sample yielded a temperature range of $590-650{ }^{\circ} \mathrm{C}$ at $7 \mathrm{kbar}$ (Zorigtkhuu et al., 2011). The matrix quartz, which contains primary fluid inclusions, is texturally in equilibrium with biotite, suggesting that the quartz might have formed during high-grade metamorphism at $T>650^{\circ} \mathrm{C}$.

The staurolite-biotite schist (sample 05-134) is composed of staurolite, chlorite, plagioclase, muscovite and ilmenite in the matrix of biotite and quartz. Staurolite is pale yellowish, coarse grained, subhedral, and contains numerous fine-grained inclusions of ilmenite. Biotite occurs in the matrix and sometimes in direct contact with staurolite. Chlorite occurs as dark greenish lepidoblasts and rarely contains rutile inclusions. Quartz grains examined for fluid inclusion analysis are texturally associated with staurolite, suggesting that quartz formed during high-grade metamorphism and the trapped fluids thus preserve near-peak metamorphic fluid.

\section{FLUID INCLUSIONS}

Doubly polished thin wafers (120-150 $\mu$ m thick) of the pelitic schist samples were prepared for petrographic and microthermometric studies of fluid inclusions. As most of fluid inclusions in the samples are generally rare and very small (less than a few microns), measurable inclusions are present only in quartz. As discussed in the previous section, the examined quartz grains are associated with highgrade minerals such as staurolite and biotite, and probably formed during prograde to peak metamorphism. The quartz-hosted fluid inclusions are classified into three types based on their occurrence: primary, pseudosecondary, and secondary (cf., Roedder, 1984) (Fig. 2). About $40 \%$ of fluid inclusions discussed in this study occur as isolated inclusions or local clusters (Fig. 2c), regarded as primary fluid inclusions that were probably trapped during the crystallization of the host mineral (quartz). Secondary inclusions are those that formed after crystallization of a mineral (Fig. 2e). Therefore, secondary inclusions are located within healed fractures, aligned along linear arrays that cut the host crystal. Such inclusions are mostly very small and not suitable for microthermometric measurements. Pseudosecondary inclusions form along micro cracks that develop during the partial growth of the crystal and form arrays that pinch out within the grains (Fig. 2d). The size and shape of the fluid inclusions in the rocks are summarized in Table 1.

Microthermometric measurements of the fluid inclusions were performed with a Linkam Heating/Freezing System at the University of Tsukuba, Japan. The measure-

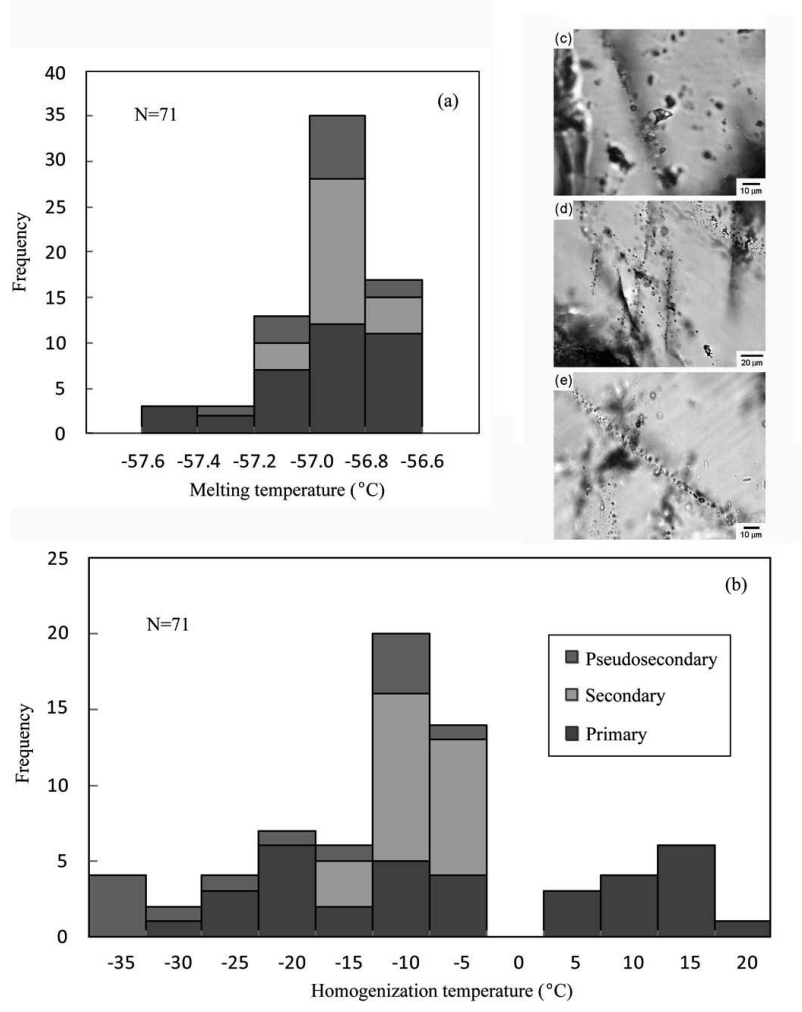

Figure 2. Histograms and photomicrographs of representative fluid inclusions. Histograms showing the distribution of melting (a) and homogenization (b) temperatures of carbonic fluid inclusions in samples 446, 24-8, 05-128, and 05-134. Photomicrographs of representative primary (c), pseudosecondary (d) and secondary (e) fluid inclusions within quartz in samples 446, 05-128, and 05-134 from Bodonch area.

ment has been done following the technique discussed in Ohyama et al. (2008). In the heating/cooling experiment, the melting temperature $\left(T_{\mathrm{m}}\right)$ and homogenization temperature $\left(T_{\mathrm{h}}\right)$ of two-phase (gas-vapour) inclusions are measured. Fluid densities and isochores were calculated using the software "MacFlinCor" developed by Brown and Hagemann (1994) based on the equation and thermodynamic data of Brown and Lamb (1989). The results from the microthermometric measurements are shown in histograms (Figs. 2a and 2b). Melting temperatures of all the inclusions $\left(-57.5^{\circ} \mathrm{C}\right.$ to $\left.-56.6^{\circ} \mathrm{C}\right)$ are close to the triple point of pure $\mathrm{CO}_{2}\left(-56.6^{\circ} \mathrm{C}\right)$, suggesting that the trapped fluids are rich in $\mathrm{CO}_{2}$. On continued heating, all the trapped fluids homogenized in to the liquid phase at temperatures in the range of $-33.3{ }^{\circ} \mathrm{C}$ to $+19.4{ }^{\circ} \mathrm{C}$. Primary fluid inclusions show wide $T_{\mathrm{h}}$ range of $-28.6{ }^{\circ} \mathrm{C}$ to +19.4 ${ }^{\circ} \mathrm{C}$, while that of secondary $\left(-11.9{ }^{\circ} \mathrm{C}\right.$ to $\left.-1.6{ }^{\circ} \mathrm{C}\right)$ and pseudosecondary $\left(-33.3{ }^{\circ} \mathrm{C}\right.$ to $\left.-5.4{ }^{\circ} \mathrm{C}\right)$ inclusions are relatively narrow. $\mathrm{CO}_{2}$ densities of the inclusions are estimated as $0.78-1.07 \mathrm{~g} / \mathrm{cm}^{3}$ (primary), $0.93-0.99 \mathrm{~g} / \mathrm{cm}^{3}$ (secondary), and $0.96-1.09 \mathrm{~g} / \mathrm{cm}^{3}$ (pseudosecondary). The 
Table 1. Summary of microthermometric measurements of carbonic fluid inclusions in pelitic schists *

\begin{tabular}{|c|c|c|c|c|c|c|c|c|c|c|c|}
\hline \multirow[t]{2}{*}{$\begin{array}{l}\text { Sample } \\
\text { no }\end{array}$} & \multirow[t]{2}{*}{$\begin{array}{l}\text { Host } \\
\text { mineral }\end{array}$} & \multicolumn{3}{|c|}{$\begin{array}{l}\text { Melting temperature } \\
\qquad\left({ }^{\circ} \mathrm{C}\right)\end{array}$} & \multicolumn{3}{|c|}{$\begin{array}{l}\text { Homogenization temperature } \\
\qquad\left({ }^{\circ} \mathrm{C}\right)\end{array}$} & \multirow[t]{2}{*}{$\begin{array}{l}\text { Density } \\
\left(\mathrm{g} / \mathrm{cm}^{3}\right)\end{array}$} & \multirow[t]{2}{*}{$\begin{array}{c}\text { Type of } \\
\text { inclusions }^{b}\end{array}$} & \multirow[t]{2}{*}{ Morphology } & \multirow[t]{2}{*}{$\begin{array}{l}\text { Size } \\
(\mu \mathrm{m})\end{array}$} \\
\hline & & Min & Max & Average $^{a}$ & Min & Max & Average $^{a}$ & & & & \\
\hline 446 & Qtz & -57.1 & -56.6 & $-56.8 \pm 0.2$ & -28.6 & 11.2 & $-9.9 \pm 10$ & $0.85-1.07$ & PR & IR, OV & $2-12$ \\
\hline 446 & Qtz & -57.2 & -56.6 & $-56.9 \pm 0.2$ & -5.4 & -33.3 & $-19.2 \pm 11$ & $0.96-1.09$ & PS & OV, IR & $4-16$ \\
\hline 446 & Qtz & -57.0 & -56.6 & $-56.8 \pm 0.1$ & -1.6 & -11.9 & $-6.5 \pm 3$ & $0.93-0.99$ & $\mathrm{SC}$ & IR, OV, TU & $3-12$ \\
\hline $24 / 8$ & Qtz & -56.9 & -56.6 & $-56.7 \pm 0.1$ & -17.8 & 19.4 & $6 \pm 11$ & $0.78-1.02$ & PR & IR, OV & $2-6$ \\
\hline $05-128$ & Qtz & -57.1 & -56.8 & $-56.9 \pm 0.1$ & -16.8 & -19.8 & $-18.4 \pm 1$ & $1.01-1.03$ & PR & OV & $6-13$ \\
\hline $05-134$ & Qtz & -57.5 & -57.2 & $-57.3 \pm 0.1$ & 11.4 & 13.1 & $12.2 \pm 0.7$ & $0.84-0.85$ & PR & $\mathrm{OV}, \mathrm{TU}$ & $2-4$ \\
\hline
\end{tabular}

${ }^{*}$ From Bodonch area, south-western Mongolia.

${ }^{a}$ Error indicates standard deviation.

${ }^{\mathrm{b}} \mathrm{PR}$, primary: PS, pseudosecondary; SC, secondary.

${ }^{\mathrm{c}} \mathrm{IR}$, irregular shape; OV, ovoidal shape; TU, tubular shape.

calculated isochores for the three types of inclusions are shown in Figure 3 together with available $P-T$ path for Bodonch area. The isochores calculated for the highest density carbonic inclusions in quartz shows a slightly lower but nearly consistent with the pressure value range of the peak condition estimated by geothermobarometers.

\section{DISCUSSION}

Microthermometric measurement of fluid inclusions in pelitic schists from Bodonch area, southwestern Mongolia, indicates that all the trapped fluids show $T_{\mathrm{m}}$ in the range of -57.5 to $-56.6{ }^{\circ} \mathrm{C}$, suggesting that the dominant fluid phase during the peak metamorphic event in this region is $\mathrm{CO}_{2}$, although slight depression in $T_{\mathrm{m}}$ might be an indicative of the presence of additional fluid components such as $\mathrm{N}_{2}$ and $\mathrm{CH}_{4}$. Homogenization of fluids occurs into liquid phase at temperature between -33.3 to $+19.4{ }^{\circ} \mathrm{C}$, which convert into densities in the range of 0.78 to 1.09 $\mathrm{g} / \mathrm{cm}^{3}$. The estimated $\mathrm{CO}_{2}$ isochores for primary and pseudosecondary high-density inclusions, which were probably trapped during the growth of the host mineral, intersect the clockwise $P-T$ trajectory of Bodonch area at around $6.4-6.8 \mathrm{kbar}$ at $660{ }^{\circ} \mathrm{C}$, which is broadly consistent with the peak metamorphic condition of the studied area (6.3-7.3 kbar at $655^{\circ} \mathrm{C}$; Fig. 3). The analyzed quartz grains are texturally associated with biotite, kyanite and staurolite, which are regarded as high-grade minerals formed during prograde to peak metamorphism. Thus, quartz probably formed by high-grade metamorphism and the primary fluid inclusions trapped in the minerals probably preserve fluids at around peak metamorphism.

The results indicate that $\mathrm{CO}_{2}$ was a dominant fluid during the peak amphibolite-facies metamorphism of this area. Available fluid inclusion studies of high-grade meta-

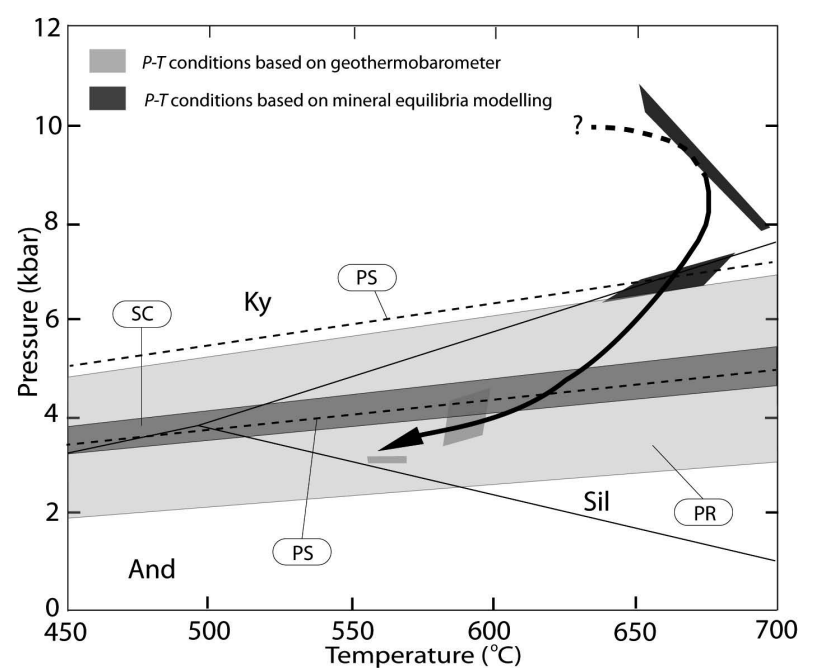

Figure 3. $P-T$ trajectory of Bodonch area (after Zorigtkhuu et al., 2011) with isochores for carbonic fluid inclusions estimated in this study. Hatched dark grey and light grey boxes indicate peak and retrograde $P-T$ conditions of the study area, respectively. The ranges of isochores for primary and secondary fluid inclusions are shown by shaded regions, also pseudosecondary fluid inclusion range is shown by dashed lines.

morphic rocks demonstrated the transition from $\mathrm{H}_{2} \mathrm{O}-$ dominant to $\mathrm{CO}_{2}$-dominant fluid inclusions in minerals while passing from amphibolite to granulite-facies rocks (e.g., Touret, 1971). It is therefore regarded that $\mathrm{CO}_{2}$ is a dominant fluid specimen during the formation of granulites, while $\mathrm{H}_{2} \mathrm{O}$-bearing fluid is abundant in amphibolitefacies metamorphism. In contrast, our first fluid inclusion study on the Mongolian Altai suggests that high-pressure amphibolite-facies event in Bodonch area is related to the activity of $\mathrm{CO}_{2}$-rich fluid. The absence of significant $\mathrm{H}_{2} \mathrm{O}$ content in the fluid inclusions contrasts with the abundant occurrence of hydrous minerals (biotite + staurolite) closely associated with the quartz grains, suggesting water- 
saturated conditions. In other words, $\mathrm{H}_{2} \mathrm{O}$-bearing inclusion was not identified in the examined rocks suggesting that the metamorphism was under dry conditions. The $\mathrm{CO}_{2}$-rich fluid inclusions reported in this study is therefore a rare example of amphibolite-facies rocks, although such near-pure $\mathrm{CO}_{2}$-rich fluid inclusions are reported from Brazilian quartz vein (Klein and Fuzikawa, 2010) and mylonite (Faleiros et al., 2010) that underwent amphibolite-facies metamorphism. The origin of $\mathrm{CO}_{2}$-rich fluid is not known, and several models such as decarbonation from carbonates and $\mathrm{CO}_{2}$ influx from sublithospheric mantle have been proposed (e.g., Santosh and Omori, 2008), oxidation of organic carbons in the protolith sedimentary rocks might be suitable to account for the $\mathrm{CO}_{2}$. Alternatively, in a subduction realm such as the CAOB, substantial amounts of intercalated carbonates were involved in the sediments, both pelagic and terrigenous rocks, and therefore carbonates that liberate $\mathrm{CO}_{2}$ at the high $P-T$ conditions could be an alternative source of $\mathrm{CO}_{2}$. Another possibility is that abundant $\mathrm{CO}_{2}$-rich fluid inclusion might be due to common occurrence of carbonates and graphite in the study area. Further carbon isotope study of the samples will be necessary to identify the source of $\mathrm{CO}_{2}$.

\section{ACKNOWLEDGMENTS}

Chemical analyses of minerals were carried out using an electron microprobe analyzer (JEOL JXA8621) at the University of Tsukuba. We thank Dr. N. Nishida for his assistance on the analyses. Prof. M. Santosh and an anonymous reviewer are acknowledged for their constructive review and detailed comments. We thank these referees as well as Dr. T. Sawaki for his editorial support. This is a contribution to the Grant-in-Aid from the Japanese Ministry of Education, Sports, Culture, Science and Technology to Tsunogae (No. 20340148, 22403017) and Prof. Y. Osanai (No. 21253008).

\section{REFERENCES}

Brown, P.E. and Lamb, W.M. (1989) P-V-T properties of fluids in the system $\mathrm{H}_{2} \mathrm{O}-\mathrm{CO}_{2}-\mathrm{NaCl}$ : new graphical presentations and implications for fluid inclusion studies. Geochimica et Cosmochimica Acta, 53, 1209-1221.

Brown, P.E. and Hagemann, S.G. (1994) MacFlinCor: a computer program for fluid inclusion data reduction and manipulation. In Fluid inclusions in minerals: methods and applications (DeVivo, B. and Frezzotti, M.L. Eds.). Short Course of the International Mineralogical Association Working Group "Inclusions in Minerals", Virginia Polytechnic Institute Press, Blacksburg, 231-250.

Chen, H.L., Li, Z.L., Yang, S.F., Dong, C.W., Xiao, W.J. and Tainosho, Y. (2006) Mineralogical and geochemical study of a newly discovered mafic granulite, northwest China: implications for tectonic evolution of the Altay Orogenic Belt. Island Arc, 15, 210-222.

Coleman, R.G. (1989) Continental growth of northwest China. Tectonics, 8, 621-635.

Faleiros, F.M., Campanha, G.A.C., Bello, R.M.S. and Fuzikawa, K. (2010) Quartz recrystallization regimes, c-axis texture transitions and fluid inclusion reequilibration in a prograde greenschist to amphibolite facies mylonite zone (Ribeira Shear Zone, SE Brazil). Tectonophysics, 485, 193-214.

Jahn, B., Wu, F. and Chen, B. (2000) Granitoids of the Central Asian Orogenic Belt and continental growth in the Phanerozoic. Geological Society of America Special Papers, 350, 181-193.

Klein, E.L. and Fuzikawa, K. (2010) Origin of the $\mathrm{CO}_{2}$-only fluid inclusions in the Palaeoproterozoic Carará vein-quartz gold deposit, Ipitinga Auriferous District, SE-Guiana Shield, Brazil: Implications for orogenic gold mineralization. Ore Geology Reviews, 37, 31-40.

Kozakov, I.K., Glebovitsky, V.A., Bibikova, E.V., Azimov, P.Ya. and Kirnozova, T.I. (2002) Hercynian granulites of Mongolian and Gobian Altai: Geodynamic setting and formation conditions. Doklady Earth Sciences, 386, 781-785.

Naganjaneyulu, K. and Santosh, M. (2011) Geophysical signatures of fluids in a reactivated Precambrian collisional suture in central India. Geoscience Frontiers, 2, 289-301.

Naidu, G.D., Manoj, C., Patro, P.K., Sreedhar, S.V. and Harinarayana, T. (2011) Deep electrical signatures across the Achankovil shear zone, Southern Granulite Terrain inferred from magnetotellurics. Gondwana Research, 20, 405-426.

Ohyama, H., Tsunogae, T. and Santosh, M. (2008) $\mathrm{CO}_{2}$-rich fluid inclusions in staurolite and associated minerals in a highpressure ultrahigh-temperature granulite from the Gondwana suture in southern India. Lithos, 101, 177-190.

Roedder, E. (1984) Fluid Inclusions. pp. 644, Reviews in Mineralogy 12, Mineralogical Society of America, Washington, D.C.

Rojas-Agramonte, Y., Kröner, A., Demoux, A., Xia, X., Wang, W., Donskaya, T., Liu, D. and Sun, M. (2011) Detrital and xenocrystic zircon ages from Neoproterozoic to Palaeozoic arc terranes of Mongolia: Significance for the origin of crustal fragments in the Central Asian Orogenic Belt. Gondwana Research, 19, 751-763.

Santosh, M. and Omori, S. (2008) $\mathrm{CO}_{2}$ windows from mantle to atmosphere: Models on ultrahigh-temperature metamorphism and speculations on the link with melting of snowball Earth. Gondwana Research, 14, 82-96.

Sengör, A.M.C., Natalin, B.A. and Burtman, V.S. (1993) Evolution of the Altaid tectonic collage and Paleozoic crustal growth in Eurasia. Nature, 364, 299-307.

Touret, J. (1971) Le facies granulite en Norwege Meridionale. Lithos, 4, 239-249.

Touret, J.L.R. (1985) Fluid regime in southern Norway: the record of fluid inclusions. In The deep proterozoic crust in the north Atlantic provinces (Tobi, A.C. and Touret, J.L.R. Eds.). Reidel, Dordrecht, 517-549.

Touret, J.L.R. (2001) Fluids in metamorphic rocks. Lithos, 55, $1-25$.

Touret, J.L.R. (2009) Mantle to lower-crust fluid/melt transfer through granulite metamorphism. Russian Geology and Geophysics, 50, 1052-1062.

Touret, J.L.R., Huizenga, J.M. (2012) Fluid-assisted granulite 
metamorphism: A continental journey. Gondwana Research, 21, 224-235.

Windley, B.F., Kröner, A., Guo, J., Qu, G., Li, Y. and Zhang, C. (2002) Neoproterozoic to Paleozoic geology of the Altai orogen, NW China: new zircon age data and tectonic evolution. Journal of Geology, 110, 719-739.

Xiao, W., Huang, B., Han, C., Sun, S. and Li, J. (2010) A review of the western part of the Altaids: A key to understanding the architecture of accretionary orogen. Gondwana Research, 18, 253-273.

Zheng, H., Qiao, E., Yang, Y. and Duan, T. (2011) Determination of inner pressure for fluid inclusions by Raman spectroscopy and its application. Geoscience Frontiers, 2, 403-407.

Zorigtkhuu, O., Tsunogae, T. and Dash, B. (2011) Metamorphic $P-T$ evolution of garnet-kyanite-staurolite schist and garnet amphibolite from Bodonch area, western Mongolian Altai: Geothermobarometry and mineral equilibrium modelling. Journal of Asian Earth Sciences, 42, 306-315.

Manuscript received October 20, 2011

Manuscript accepted January 20, 2012

Published online February 18, 2012

Manuscript handled by Takayuki Sawaki 